\title{
EFFECT OF CHRONIC LOW DOSE ACRYLAMIDE ON THE ULTRASTRUCTURE AND APOPTOSIS OF ADRENAL GLAND CORTEX IN ADULT FEMALE ALBINO RAT
}

\author{
By \\ Omnia S. Erfan and Mona A. El-Shahat \\ From \\ Department of Anatomy, Faculty of Medicine, Mansoura University
}

\begin{abstract}
Introduction: Endocrine disturbances to the thyroid and adrenals were observed due to acrylamide exposure.

Aim of the work: to detect any alteration in the ultrastructure and apoptosis in the cortex of adrenal gland after exposure to acrylamide.

Material \& methods: 16 female albino rats were separated into two groups, group I acting as control and rats in group II received $10 \mathrm{mg} / \mathrm{kg}$ body weight of acrylamide by oral gavages for 3 months. The adrenal glands were removed and processed for electron microscopy and histological examination. Sections were stained with $\mathrm{Hx} \& \mathrm{E}$ and $\mathrm{Bax}$ and $\mathrm{Bcl}-$ 2 immunohisochemistry.
\end{abstract}

155
Results: In the ACR group, the rounded or arched clusters of $Z G$ and the parallel columns of ZF were less apparent with narrowing of capillaries that may indicate the presence of swelling. By TEM, electron lucent areas were observed in the cytoplasm of ZG cells and many mitochondria showed defects. Many cells of ZF showed cytoplasmic vacuoles of irregular shape and electron lucent areas in the mitochondria. The expression of Bax in the cortex was significantly higher in the ACR group while the $\mathrm{Bcl}-2$ expression was significantly decreased in the acrylamide treated group compared to the control group. Conclusion: The cellular and mitochondrial changes and the increase in the $\mathrm{Bax}$ to $\mathrm{Bcl}-2$ expression ratio indicated increase in the direction of apoptotic pathway MANSOURA MEDICAL JOURNAL 
in the cortex of adrenal gland due to exposure to ACR.

Key wards: adrenals, acrylamide, ultrastructure, apoptosis, Bax, Bcl-2.

\section{INTRODUCTION}

Acrylamide (ACR) is an important industrial chemical with many uses in its polymeric forms [1]. Although accidental exposure to ACR can be significant for some occupations [2], the principal route of human exposure is through the diet because ACR is formed during the cooking of many common starchy foods [3].

Exposure to ACR is a toxicological concern because it is chemically reactive, particularly with thiol groups [4], causes peripheral neuropathy in laboratory animals [5] and humans [2], germ cell mutations and reproductive disorders in animals [6], and is carcinogenic in multiple tissues of chronically exposed rodents [1]. Endocrine disturbances to the thyroid and adrenals were also observed due to acrylamide exposure $[7,8]$. Some histological changes were noticed in the adrenal gland after acrylamide exposure [8]. Although some studies described ultrastructural changes induced by ACR on rat tes- tis [9], human astrocytoma cells [10] and trophozoites [11], the effect on adrenal cortex was not described before.

Acrylamide was shown to induce apoptosis of cerebral cortex neurons [12], testis [13] and human astrocytoma cells [10]. Apoptosis, a selective process of physiological cell deletion, is induced by DNA damage or oxidative stress [13]. Members of the $\mathrm{Bcl}-2$ family regulate apoptosis via two classes, anti-apoptotic (Bcl-2, $\mathrm{Bcl}-\mathrm{XL}$ and $\mathrm{Bcl}-\mathrm{w}$ ) or pro-apoptotic (Bax, Bak and Bad) [14]. Imbalance between the proapoptotic and antiapoptotic stimuli can direct the cell toward apoptosis.

So the aim of this study is to detect any alteration in the ultrastructure and apoptosis in the adrenal gland cortex.

\section{MATERIAL \& METHODS}

Experimental animals:

Sixteen adult female albino rats weighing $150-180 \mathrm{~g}$ were used in this study. They were kept in environmentally controlled room $\left(22 \pm 2 \mathrm{C}^{\circ}\right.$, $12 \mathrm{~h}$ light $/ 12 \mathrm{~h}$ dark cycle) and allowed free access to food and water. All rats received care in according to 
the rules and regulations of the Medical Research Ethics Committee of Mansoura Faculty of Medicine.

\section{Experimental Design:}

After an acclimatization period of one week, the rats were randomly separated into two groups of eight, with those in group I acting as the untreated controls and provided with tap water during the entire period of the study. Rats in group II received $10 \mathrm{mg} / \mathrm{kg}$ body weight of acrylamide (Sigma, Egypt) dissolved in tab water $(1 \mathrm{mg} / \mathrm{ml})$ by oral gavages once in the morning for 3 months. The rats were isolated from males throughout the experiment. At the last four days of experiment, vaginal smears using cotton bud moistened with saline were done at 11 o'clock in the morning for oestrous cycle evaluations. The slides were examined and rats in the diestrous phase were sacrificed after ether anesthesia by decapitation and the adrenal gland was immediately removed and the right gland was processed for histology and the left for electron microscopy.

\section{Histological processing:}

The adrenal gland tissue was fixed in $10 \%$ buffered formalin, embedded in paraffin, cut into $3-5 \mu$ thick sections and stained with haematoxylin and eosin.

Transmission Electron Microscopy (TEM):

The adrenal gland tissue was cut into small pieces (approx. 1-mm3 cubes), fixed in $3 \%$ glutaraldehyde (in $0.1 \mathrm{M}$ phosphate buffer, $\mathrm{pH} 7.4$ ) at $4^{\circ} \mathrm{C}$ for $1 \mathrm{~h}$, washed and fixed in $1 \%$ osmium tetroxide (in phosphate buffer) at room temperature for $1 \mathrm{~h}$. Tissue was then washed in water, dehydrated in graded ethyl alcohol and embedded in araldite. Ultrathin sections were cut, stained with uranyl acetate and lead citrate and photographed under a Jeol transmission electron microscope (JEM-2100, Japan) at the Electron Microscopy Unit, Mansoura University.

\section{Immunohistochemistry:}

Immunohistochemical staining to determine $\mathrm{Bax}$ or $\mathrm{Bcl}-2$ expression was done according to the manufacturer instructions. Briefly, sections were deparaffinised in xylene and rehydrated by immersion in descending concentrations of ethanol. Sections were treated with $3 \%$ hydrogen peroxide to block endogenous peroxidases, subjected to routine heat antigen retrieval procedures then incu-

MANSOURA MEDICAL JOURNAL 
bated with a primary antibody raised against Bax (Abcam, Egypt) or Bcl-2 (Abcam, Egypt) overnight at $4^{\circ} \mathrm{C}$. After washing with phosphate buffer saline (PBS) (PH7.4), the sections were incubated with secondary antibodies using ABC Detection IHC Kit (Abcam, Egypt). The cells that displayed brown precipitation were considered to be positive for Bax or Bcl2 expression.

\section{Morphometrical analysis:}

The measurements were done on digital photomicrographs of the immunohistochemically stained sections for $\mathrm{Bax}$ and $\mathrm{Bcl}-2$ using the software ImageJ programme. Twothree random fields per section and two sections per animal in each group were used. The colour deconvolution plugin feature of ImageJ programme was used to calculate the percentage of the color optical density.

\section{Statistics:}

All values were expressed as mean $\pm S E M$. Significant differences between the groups were determined by performing one-way ANOVA followed by student t-test. The criterion for statistical significance was set at $p<0.05$.

Vol. 43, No. 1 \& 2 Jan. \& April, 2014

\section{RESULTS}

\section{Adrenal gland histology:}

Control group. The gland was formed of an outer cortex composed of three zones; zona glomerulosa $(\mathrm{ZG})$, zona fasciculata (ZF) and zona reticularis $(\mathrm{ZR})$ and inner medulla. The zona glomerulosa was the outermost zone and consisted of cells arranged in rounded or arched clusters. The zona fasciculata was the middle and thickest zone and was composed of parallel columns of cuboidal or polyhedral cells, one to two cells thick, separated by prominent capillaries. The cytoplasm appeared foamy due to dissolved intracellular lipid droplets. The zona reticularis was made of smaller cells forming a network of interconnected cords (Fig. 1A\&B).

Acrylamide group. The rounded or arched clusters of $Z G$ and the parallel columns of ZF were less apparent. There was narrowing of capillaries which may indicate swelling of its cells (Fig. 2A\&B).

\section{Adrenal gland ultrastructure:}

Control group. The cells of $Z G$ had round or oval euchromatic nuclei with some heterochromatin especially close to the nuclear membrane 
Omnia S. Erfan and Mona A. El-Shahat et al...

and prominant nucleoli. The cyto-

Immunohistochemistry:

plasm contained numerous mito-

Bax immunohistochemistry. chondria, dark lipid droplets and Weak or moderate reaction was some lysosomes (Fig. 3). The cells of ZF had large euchromatic nuclei with prominent nucleolei. The mitochondria were more numerous than $Z G$ while the lipid droplets were smaller. Lumina of numerous capillary vessels were visible in both zones (Fig. 5).

Acrylamide group. The nuclei of ZG contained more condensed chromatin compared to control. Electron lucent areas were observed in the cytoplasm and many mitochondria showed defects (Fig. 4). Vacuoles of irregular shape appeared in the cytoplasm of many cells of ZF. Electron lucent areas were also observed in the mitochondria. Lumina of the capillary vessels were narrower in the ZF (Fig. 6). observed in many cells of ZF of the control adrenals with only few cells showed strong reactivity in their cytoplasm. In the ACR group, there was increase in the reactivity and many cells showed moderate or strong stain (Fig. 7A\&B). The expression of bax was significantly higher in the ACR group as detected by optical density (Fig. 8).

Bcl-2 immunohistochemistry. The cells of the $Z G$ showed more reaction for the prosurvival protein $\mathrm{Bcl}-2$ than the ZF (Fig. 9). The reaction in the cortex was significantly decreased in the acrylamide treated group than the control group (Fig. 10). 


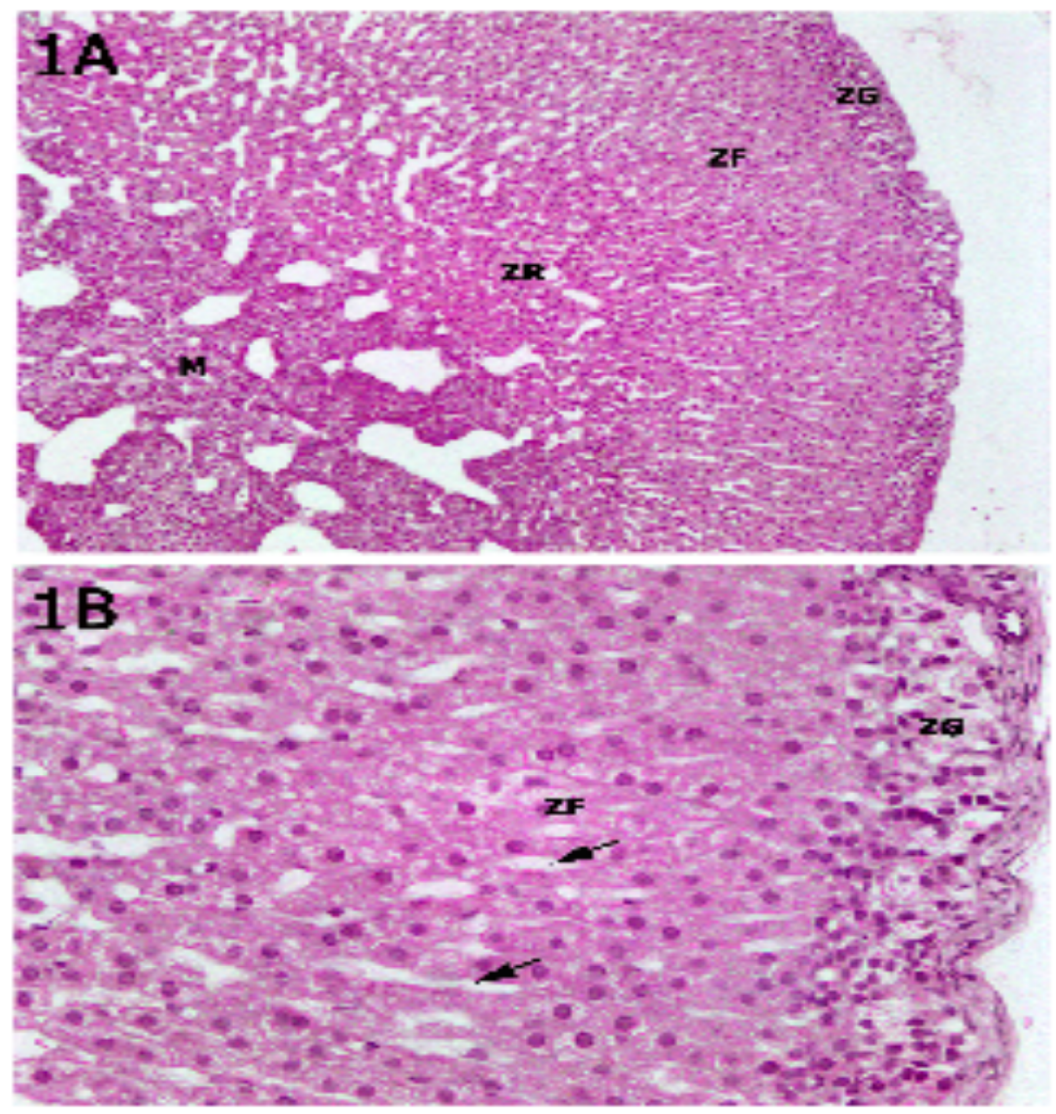

Fig. 1. (A) A photomicrograph of an adrenal gland section from an adult female albino rat of the control group showing the three zones of the cortex (zona glomerulosa, ZG, zona fasciculata, ZF, and zona reticularis, ZR) and medulla (M). (B) A higher magnification viewing $\mathrm{ZG}$ that consisted of cells arranged in rounded or arched clusters. The ZF was the thickest zone and was composed of parallel columns of secretory cells with foamy cytoplasm (intracellular lipid droplets) separated by prominent capillaries (arrows).

Hx\&E; A x40, B x 100

Vol. 43, No. 1 \& 2 Jan. \& April, 2014 
Omnia S. Erfan and Mona A. El-Shahat et al...
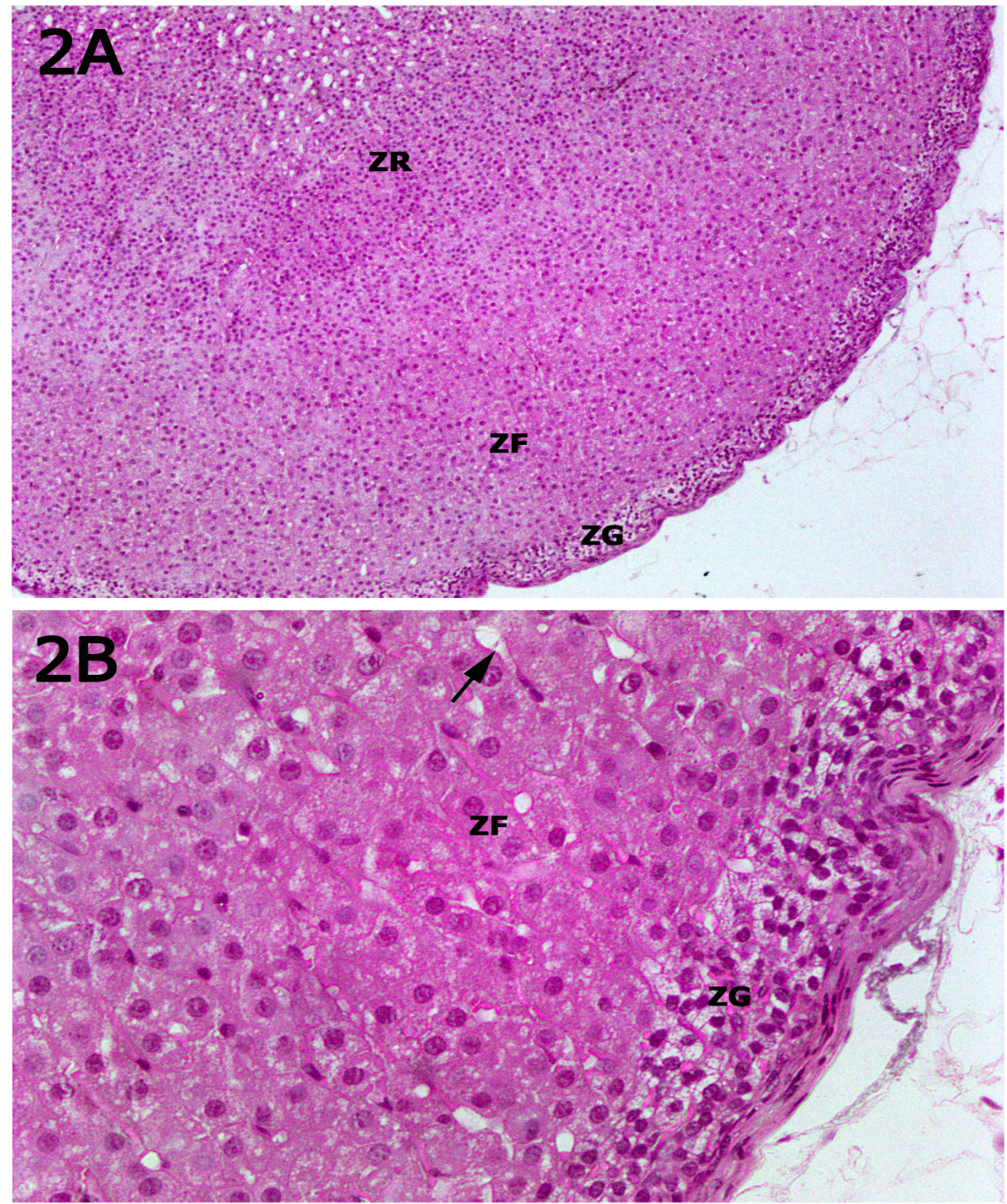

Fig. 2. (A) A photomicrograph of an adrenal gland section from an adult female albino rat of the acrylamide treated group showing its different layers. (B) The rounded or arched clusters of zona glomerulosa (ZG) and the parallel columns of zona fasciculate (ZF) are less apparent and separated by narrower capillaries (arrow).

Hx\&E; A x 40, B x 100 


\section{EFFECT OF CHRONIC LOW DOSE ACRYLAMIDE etc...}

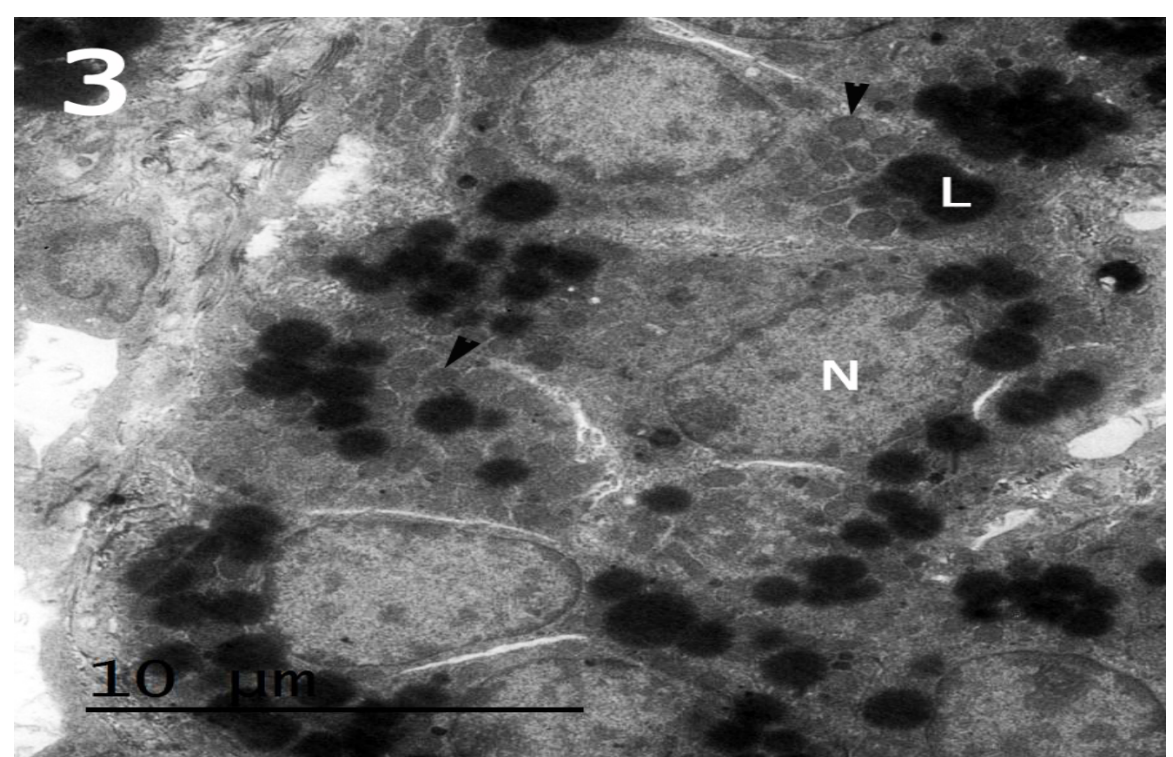

Fig. 3. An electron photomicrograph of the zona glomerulosa of the control group showing cells with round or oval euchromatic nuclei (N). Dark lipid droplets (L) and numerous mitochondria (arrow heads) are seen in the cytoplasm.

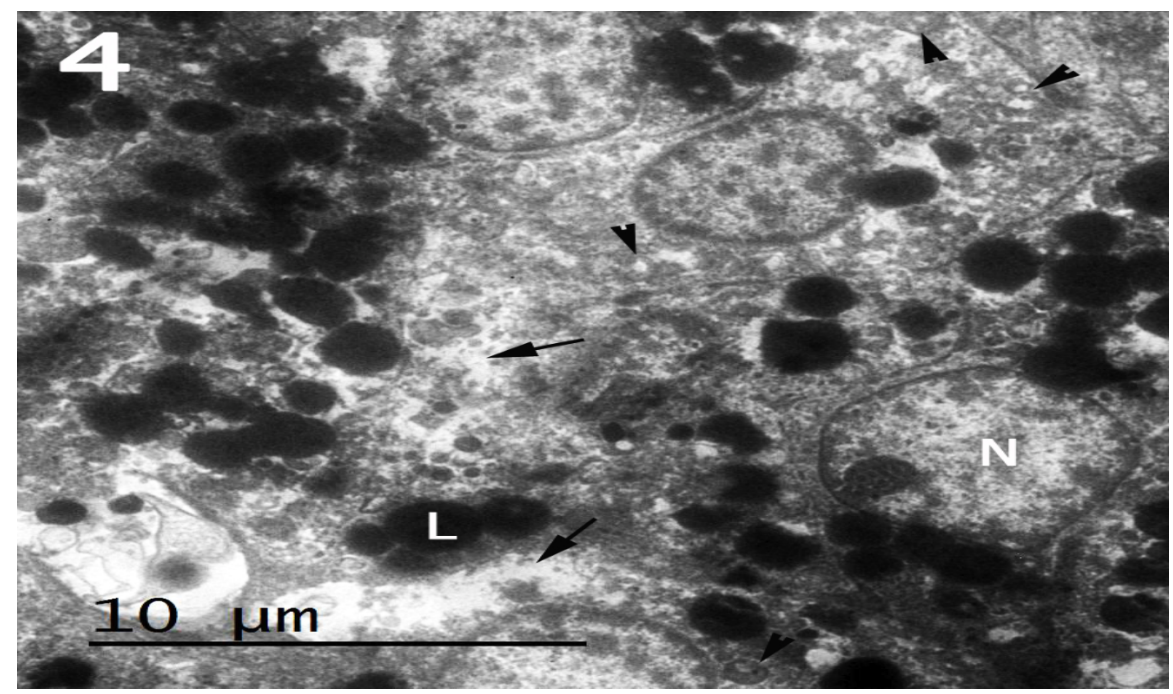

Fig. 4. An electron photomicrograph of the zona glomerulosa of the acrylamide-treated group showing cells with round or oval nuclei $(\mathrm{N})$ but with more condensed chromatin compared to control. Dark lipid droplets (L) are seen. Electron lucent areas are observed in the cytoplasm (arrows) and vacuolated mitochondria (arrow heads) are present.

Vol. 43, No. 1 \& 2 Jan. \& April, 2014 
Omnia S. Erfan and Mona A. El-Shahat et al...

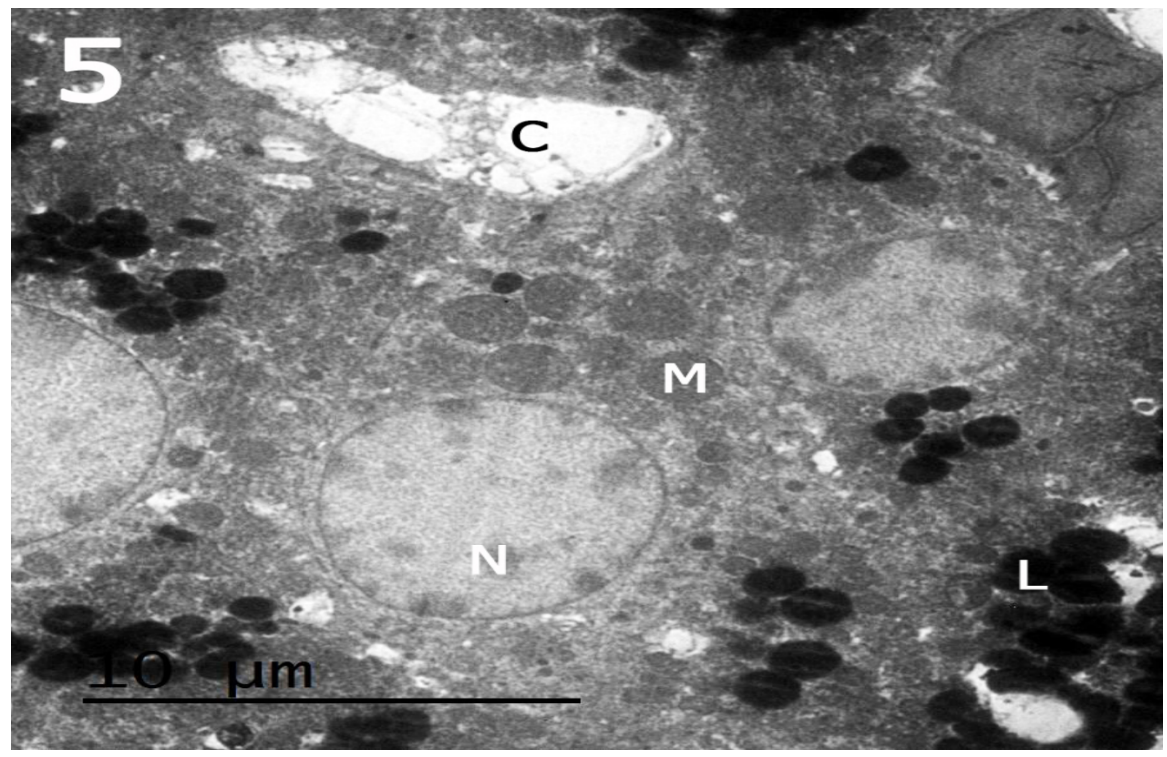

Fig. 5. An electron photomicrograph of the zona fasiculata of the control group showing large euchromatic nuclei $(\mathrm{N})$. The mitochondria $(\mathrm{M})$ are more numerous while the lipid droplets (L) are smaller than those in zona gromerulosa. A lumen of capillary vessel (c) is visible.

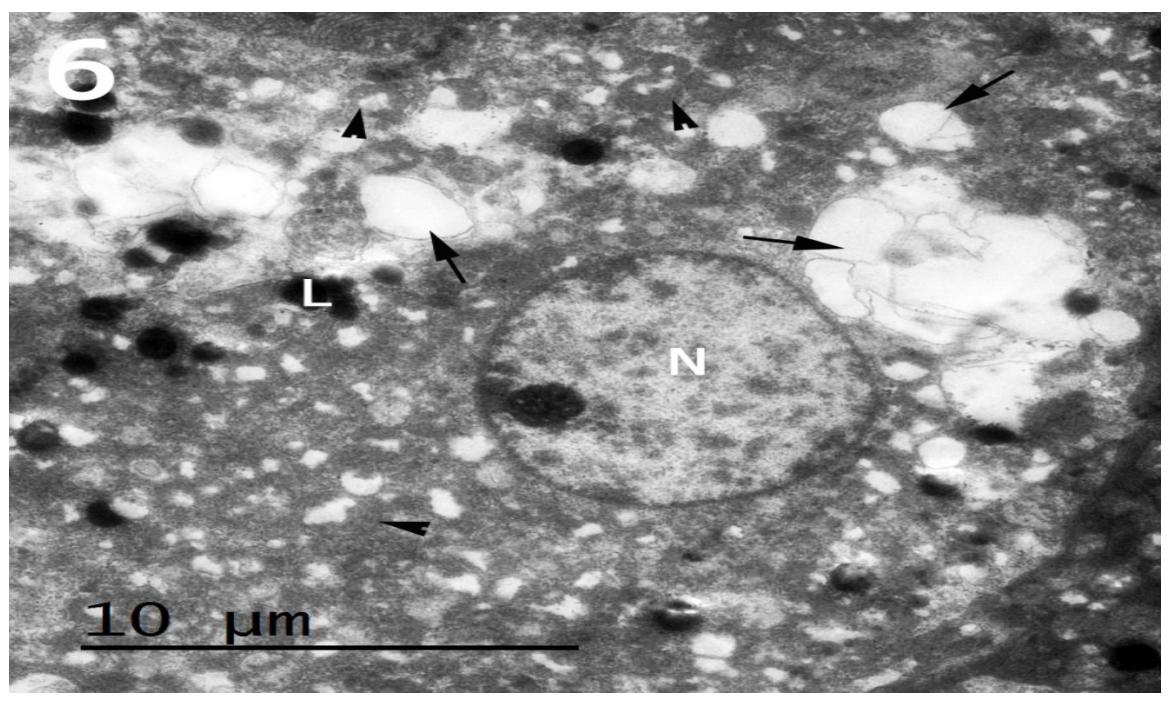

Fig. 6. An electron photomicrograph of the zona fasiculata of the acrylamide-treated group showing vacuoles (arrows) in the cytoplasm and in the mitochondria (arrow heads). 

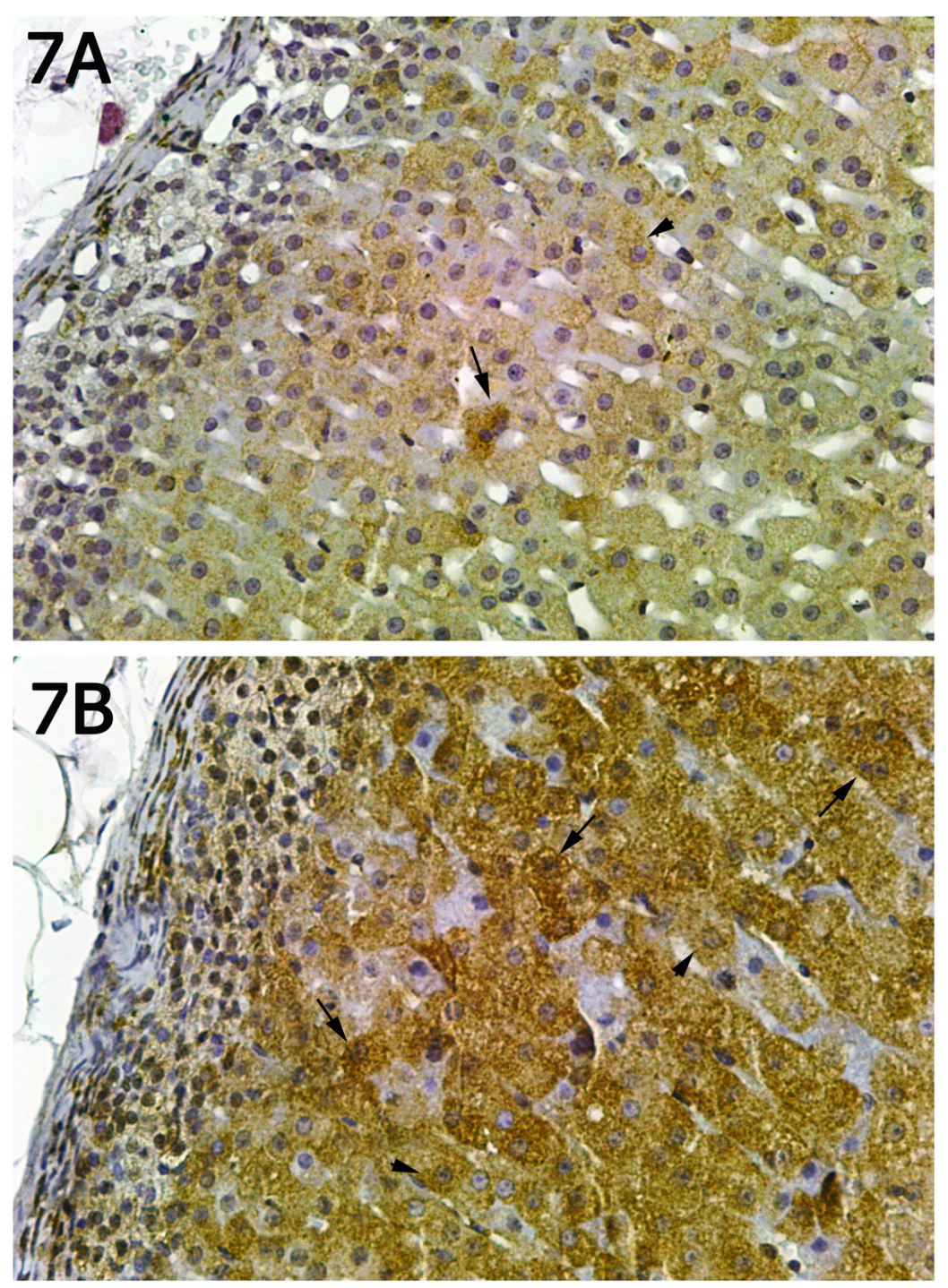

Fig. 7. Photomicrographs of adrenal sections from control (A) and acrylamide (B) groups. Weak or moderate (arrow head) expression of Bax was observed in many cells of ZF of the control adrenals with only few cells showed strong reactivity (arrow) in their cytoplasm. In the ACR group, there was increase in the reactivity and many cells showed moderate (arrow head) or strong (arrow) stain. Bax immunohistochemistry; $x 100$

Vol. 43, No. 1 \& 2 Jan. \& April, 2014 


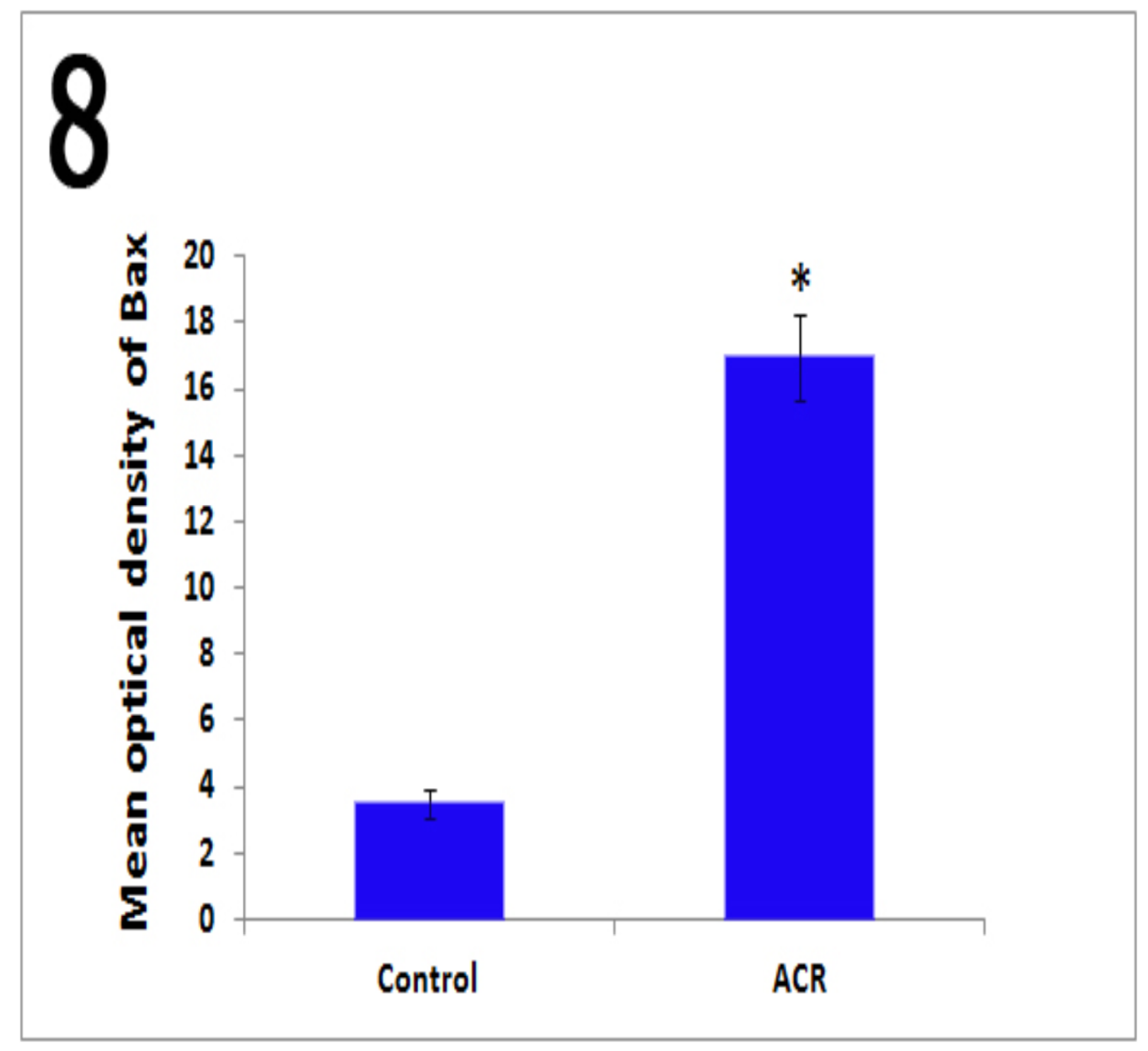

Fig. 8. A histogram showing the mean optical density of Bax expression in both ZG and ZF. Bax expression was significantly higher (*) in the ACR group as compared to control, $\mathrm{P}<0.05$ 


\section{EFFECT OF CHRONIC LOW DOSE ACRYLAMIDE etc...}
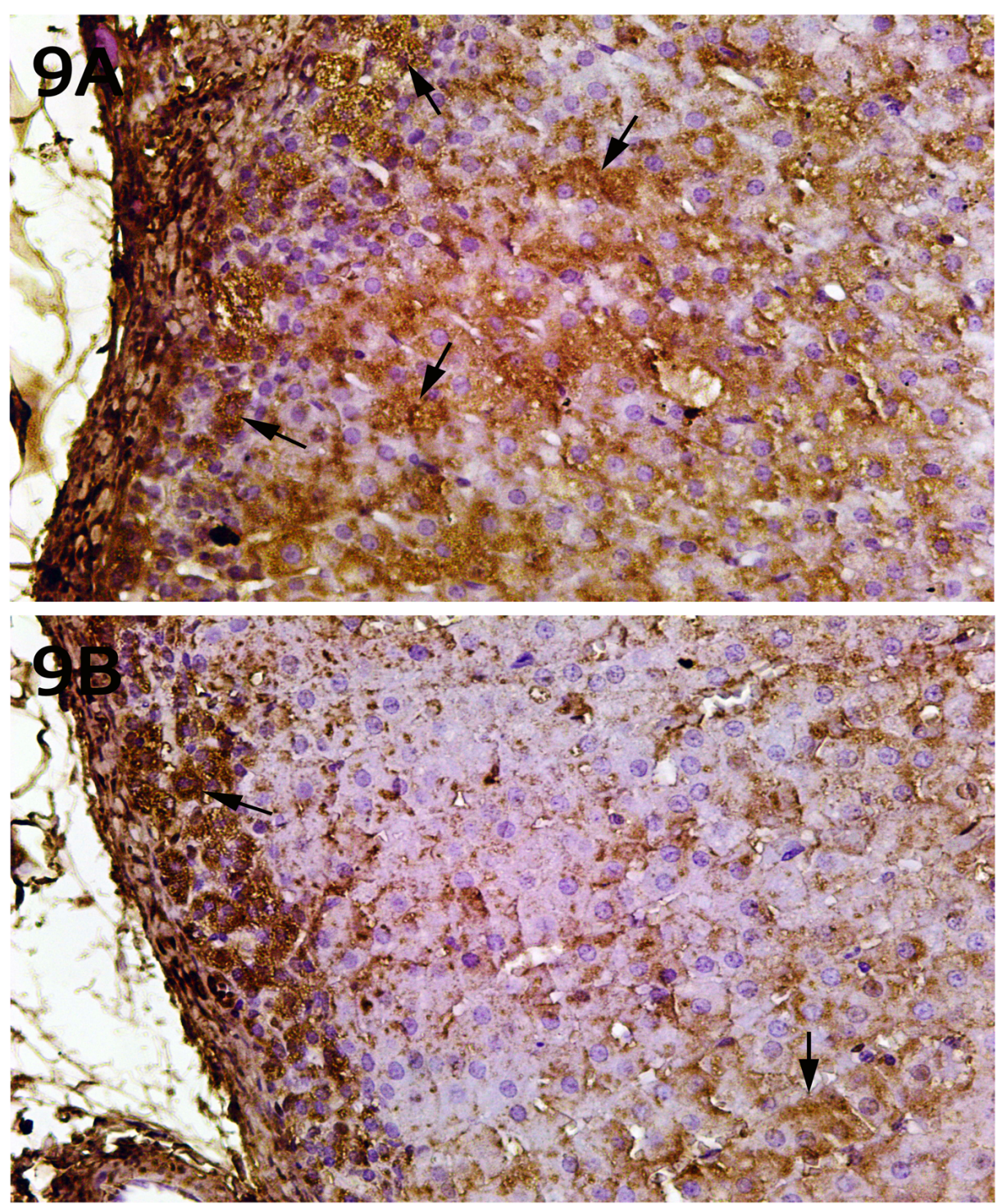

Fig. 9. Photomicrographs of adrenal sections from control (A) and acrylamide (B) groups. The reaction (arrows) of the prosurvival protein Bcl-2 in the cortex was significantly decreased in the acrylamide treated group than the control group.

Bcl-2 immunohistochemistry; x100

Vol. 43, No. 1 \& 2 Jan. \& April, 2014 
Omnia S. Erfan and Mona A. El-Shahat et al...

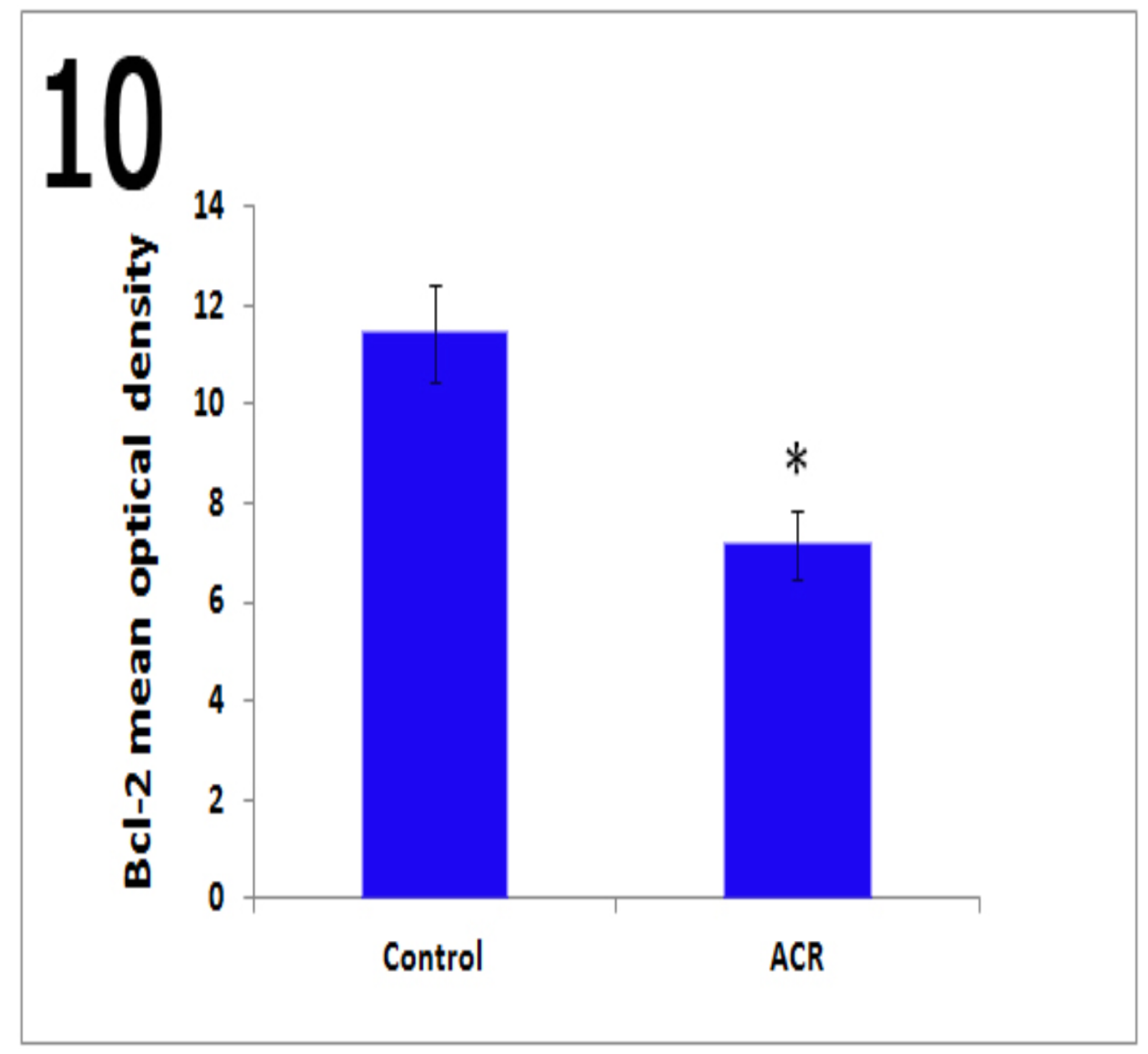

Fig. 10. A histogram showing the mean optical density of Bcl-2 expression in both ZG and ZF. Bcl-2 expression was significantly lower (*) in the ACR group as compared to control, $\mathrm{P}<0.05$ 


\section{DISCUSSION}

The adrenal gland is the most commonly associated with chemically induced lesions among the endocrine organs [15]. Previous works indicated that the adrenal gland could be affected by acrylamide (ACR) exposure. A significant decrease in serum corticosterone level [16,8] and histological changes in the form of cytoplasmic vacuolation of adrenal zona fasciculata were observed after 8weeks of ACR treatment [8]. However, in the present study vacuolation was not visible in the histological sections but obvious reduction in the capillary size was seen in the zona fasciculata which may indicate swelling of its cells. Although some studies described ultrastructural changes induced by ACR on rat testis [9], human astrocytoma cells [10] and trophozoites [11], the effect on adrenal cortex ultrastructure was not described before. In this study, oral administration of ACR in a moderately low dose for 3 months resulted in more condensation of heterochromatin in the nuclei of both zona glomerulosa and fasciculata compared to control. The cytoplasm showed electron lucent areas especially in the $Z F$, fragmentation of endoplasmic reticulum and vacuolation of the mito- chondria. Chen et al. [10] also observed mitochondrial changes in human astrocytoma cells in the form of marked vesicular matrix compartmentalization. Mitochondrial damage can result from oxidative stress which was observed to increase after ACR exposure [16,17,18]. ACR forms adducts with sulfhydryl groups on proteins with the major site of reaction is cysteine residue [4]. The sulfhydryl functional group of cysteine has a crucial role in protecting the cell from oxidative damage [19].

The adrenal gland is subjected to balanced dynamic structural changes including cellular proliferation and death to ensure integrity and functionality of the adrenal gland [20]. Apoptosis is a natural cell elimination process, important during tissue turnover [21] characterized by activation of caspases and execution of cell death. Members of the $\mathrm{Bcl}-2$ family proteins direct the fate of a cell towards either survival or death by the opposing action of the antiapoptotic (Bcl-2, Bcl-XL and Bcl-w) or pro-apoptotic proteins (Bax, Bak and $\mathrm{Bad}$ ) [14]. In the mitochondrial pathway of apoptosis, the cytosolic harmless monomer Bax becomes changed into deadly oligomer that 
Omnia S. Erfan and Mona A. El-Shahat et al...

translocates to mitochondria upon exposure to various cytotoxic agents $[22,23]$. This results in permeabilization of the mitochondrial outer membrane and release of proapoptotic factors such as cytochrome $c$ to the cytoplasm that initiates a proteolytic cascade [23]. Members of the antiapoptotic family, Bcl-2 and Bcl-xL, can inhibit or delay this release thus significantly prevent cell death [24]. In the present study, the expression of Bax was significantly higher in the ACR group as detected by optical density. This was accompanied with a significant reduction in $\mathrm{Bcl}-2$ expression indicating increase in the direction of apoptotic pathway. In the cerebral cortex of rats exposed to ACR, similar effects were also observed by [12].

Conclusion: Acrylamide induced damage to the adrenal gland cortex probably through increasing oxidative stress that targets the mitochondria as shown from the electron $\mathrm{mi}$ croscopic changes and the expression of Bax and $\mathrm{Bcl}-2$.

\section{REFERENCES}

1. Bowyer JF, Latendresse JR, Delongchamp RR, et al.
(2008) : The effects of subchronic acrylamide exposure on gene expression, neurochemistry, hormones, and histopathology in the hypothalamuspituitary-thyroid axis of male Fischer 344 rats. Toxicol Appl Pharmacol. 230 (2):208-215.

2. Hagmar L, Tornqvist $M$, Nordander et al. (2001) : Health effects of occupational exposure to acrylamide using hemoglobin adducts as biomarkers of internal dose. Scand. J. Work, Environ. Health 27, 219-226.

3. Tareke E, Rydberg P, Karlsson P, et al. (2002) : Analysis of acrylamide, a carcinogen formed in heated foodstuffs. J. Agric. Food Chem. 50:4998-5006.

4. LoPachin RM, Barber DS and Gavin T (2008) : Molecular mechanisms of the conjugated $\alpha$-unsaturated carbonyl derivatives: relevance to neurotoxicity and neuro-

MANSOURA MEDICAL JOURNAL 
EFFECT OF CHRONIC LOW DOSE ACRYLAMIDE etc...

degenerative diseases.

Toxicol. Sci. 104 (2):235-

249.

5. LoPachin RM, Balaban CD and Ross JF (2003) : Acrylamide axonopathy revisited. Toxicol. Appl. Pharmacol. 188:135-153.

6. Dearfield KL, Douglas GR, Ehling UH, et al. (1995) : Acrylamide: a review of its genotoxicity and an assessment of heritable genetic risk. Mutat. Res. 330:71-99.

7. Khan MA, Davis CA, Foley GL et al. (1999) : Changes in thyroid gland morphology after acute acrylamide exposure. Toxicological sciences 47:151-157.

8. Hamdy SM, Bakeer HM, Eskander EF et al. (2012) : Effect of acrylamide on some hormones and endocrine tissues in male rats. Hum Exp Toxicol. 31 (5):483-491.

9. Mustafa HN (2012) : Effect of Vol. 43, No. 1 \& 2 Jan. \& April, 2014 acrylamide on testis of albino rats. Ultrastructure and DNA cytometry study. Saudi Med. J. 33(7):722-731.

10. Chen JH, Yang $\mathbf{C H}$, Wang YS, et al. (2013) : Acrylamideinduced mitochondria collapse and apoptosis in human astrocytoma cells. Food Chem. Toxicol. 51:446-452.

11. Abdelmeguid N (1990) : Effect of acrylamide toxicity on the ultrastructure of a single cell model Nyctotheroides puytoraci. Int. J. Parasitol. 20(7):861-865.

12. Lakshmi D, Gopinath K, Jayanthy $G$ et al. (2012) : Ameliorating Effect of Fish Oil on Acrylamide Induced Oxidative Stress and Neuronal Apoptosis in Cerebral Cortex. Neurochem. Res. 37 : 1859-1867.

13. Zhang $X$, Chen $F$ and Huang $Z$ (2009) : Apoptosis induced by acrylamide is suppressed in a $21.5 \%$ fat diet through caspase-3- 
Omnia S. Erfan and Mona A. El-Shahat et al...

independent pathway in

mice testis. Toxicology

Mechanisms and Methods

19 (3): 219-224.

14. Yang $E$ and Korsmeyer SJ (1996) : Molecular apoptosis: a discourse on the $\mathrm{Bcl} 2$ family and cell death. Blood 88: 386- 401.

15. Ribelin WE (1984): The effects of drugs and chemicals upon the structure of the adrenal gland. Fundam. Appl. Toxicol. 4: 105-119.

16. Shuming $C$, Jilin $F$ and $X i-$ chun $Z$ (2009) : The moderating role of dark soy sauce to acrylamideinduced oxidative stress and neurophysiological perturbations in rats. Toxicol. Mech. Methods. 19(67):434-440.

17. Prasad SN and Muralidhara (2012) : Evidence of acrylamide induced oxidative stress and neurotoxicity in Drosophila melanogaster its amelioration with spice active enrichment: relevance to neuropathy. Neurotoxicology 33(5):12541264.

18. Yousef $\mathrm{MI}$ and El-Demerdash FM (2006) : Acrylamideinduced oxidative stress and biochemical perturbations in rats. Toxicology 219(1-3):133-141.

19. Requejo R, Hurd TR, Costa NJ et al. (2010) : Cysteine residues exposed on protein surfaces are the dominant intramitochondrial thiol and may protect against oxidative damage. FEBS Journal 277:1465-1480.

20. Nussdorfer GG (1986) : Cytophysiology of the adrenal cortex. Int. Rev. Cytol. 98:1-405.

21. Smaili SS, Hsu Y-T, Sanders KM, et al. (2001) : Bax translocation to mitochondria subsequent to a rapid loss of mitochondrial membrane potential. Cell Death and Differentiation (2001) 8:909 -920.

MANSOURA MEDICAL JOURNAL 
172 EFFECT OF CHRONIC LOW DOSE ACRYLAMIDE etc...

22. Hsu YT, Wolter KG and Youle

RJ (1997) : Cytosol-tomembrane redistribution of Bax and $\mathrm{Bcl}-\mathrm{X}(\mathrm{L})$ during apoptosis. Proc. Natl. Acad. Sci. USA 94: 3668-3672.

23. Westphal D, Kluck RM and Dewson G (2014) : Building blocks of the apoptotic pore: how Bax and Bak are activated and oligomerize during apoptosis. Cell Death and Differentiation $21: 196-205$.

24. Finucane DM, Bossy-Wetzel EB, Waterhouse NJ, et al. (1999) : Bax-induced Caspase Activation and Apoptosis via Cytochrome c Release from Mitochondria Is Inhibitable by Bcl-xL. The Journal of Biological Chemistry $74(4), 2225-2233$. 


$$
\text { الملاخسص العربى }
$$

\section{التأثير المزمن لجرعة منخفضة من الأكريـالمايد على التركيب}

$$
\text { الدقيق والموت المبـرهج فى قشرة الغدة الكظريـة فى }
$$

إناث الجرذان البيضاء البالغة

$$
\text { أمنية عرفان و منى الشحات }
$$

قسم التشريح ، كلية الطب ، جامعة المنصورة

التحلعمهد لقد لوحظ وجود اضطراب فى نشاط الغدد الصماء مثل الغده الدرقيه والكظريه بعد

الغرض من البمث : اكتشـاف أى تغـيـرات فى التـركيب الدقيق والموت المبـرهـج فى قشـرة الغدة الكظريـة نتيجة التعرض لكلأكريلامايد.

المواد والطرق المستخدمه ؛ لقد تم استخدام 17 أنثى فأر أبيض في هذه التجربه تم تقسيههم الى مـجموعيتين الاولى قياسيه و الثانيه أخذت الأكريلامايد بجرعة ـ ا مـج/كجم من وزن الجسمى عن طريق الفهم لمدة س شهور. وتم استئصسال الغدد الكظريه ومعالجتها للميكروسكوب الإليكترونى والفـحص الهيستولكوجى. وتمت صبـاغة الشرائح بـالهيمـاتوكسـلين والإيـوسين والصبغــة المناعية الهيستوكيميائية باكس و بى سى ال تو.

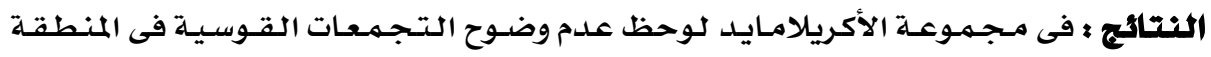
الحبيـبـية واعمـدة المتـوازيـة مـن الخلايـا فى المنطقة الحـزمـية كمـا وجــ ضيق فى الاوعيه الدمويه وهـا قد يشـير الى وجود تورم فى الخلايا ـ بالميكروسكوب الانكترونى وجـدت فراغات فى سيتوبلازم 
174 EFFECT OF CHRONIC LOW DOSE ACRYLAMIDE etc...

الخلايا فى منطقة المنطقـة الحبيبية وفراغات فى كثير من الميتوكوندريا. وكثير من خلايا المنطقة

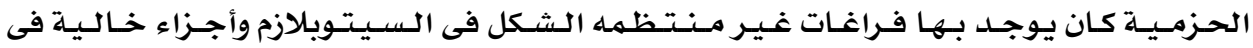
الميتوكوندريا . , أظهرت الصبـغـات المنـاعية زيـادة فى البـاكس فى مسجمـوعـة الاكريلامـايــ بـالمقارنه

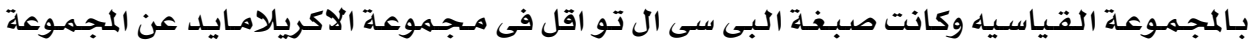
القياسيـه.

الاستثتاج : التغيرات التى لوحظت فى الخلايا والميتوكوندريا مـع الزيادة فى نسبة البـاكس الى البى سـى إل تو تشيـر إلى زيـادة فى الإتجاه الموت المبـرمج للـخلايـا فى قشرة الغدة الكظريـه نتيـجة للتعرض كلأكريلامايد.

Vol. 43, No. 1 \& 2 Jan. \& April, 2014 